DOI: 10.21625/resourceedings.v2i3.638

\title{
Space as Symbol in Sacred Architecture. The Problem of Christian Sacred Architecture
}

\author{
Zorana Sokol Gojnik ${ }^{\mathbf{1}}$, Igor Gojnik ${ }^{\mathbf{2}}$ \\ ${ }^{1}$ Faculty of architecture, Zagreb, Croatia \\ ${ }^{2}$ Siloueta architecture, Zagreb, Croatia \\ Email:zorana.sokol@arhitekt.hr
}

\begin{abstract}
In contemporary research (theoretical and architectural projects) of Christian sacred architecture it has been observed that there is a lack of understanding of the phenomenon of space as one of the symbols of sacred architecture.

The goal of this paper is to point out the importance of observing the space (architecture) as a sacred symbol, because a problem has been recognised, dealing with the lack of fundemantel definition in the interpretation of the sacred space.

In this paper, the research will be carried out by a comparative analysis of the religious concepts of the great religions of Hinduism, Buddhism, Judaism, Christianity, and Islam, as well as their materialisation through space.

The expected result of the research is to confirm the hypothesis that space, as well as rituals, images, artistic works, etc. in sacred architecture has the role of a symbol. Space has the task of keeping the basic concepts of religions and of being a mediator of the experience of faith.

(C) 2019 The Authors. Published by IEREK press. This is an open access article under the CC BY license (https://creativecommons.org/licenses/by/4.0/).
\end{abstract}

\section{Keywords}

Sacred architecture, symbol, Christianity, space

\section{Introduction}

In contemporary research (theoretical and architectural projects) of Christian sacred architecture, it has been observed that there is no understanding of the phenomenon of space as an important symbol of sacred architecture. The theoretical studies are dominated by the analysis of sacred architecture through the analysis of typology, composition, stylistic features, historical analysis etc., but there is a lack of comprehending space itself as a religious symbol. The goal of this paper is to point out the importance of comprehending the architectural space as a sacred symbol. The word symbol (Greek symballon) in its etymology, means connecting together. The symbol connects two realities, and through one reality it opens the horizon of another reality. In the case of the phenomenon of the sacred, the reality of space, artistic works, rituals and other phenomena of living reality is being associated with the transcendental phenomenon of each religion. In that dynamism there is the comprehending and experience of faith (Guardini, 1998, Hani, 1996; Šaško, 2005). In the symbol and through the symbol, reality is felt and experienced, so it follows that symbols have their mystagogic character, and they introduce the faithful in the mysterious dimension of faith. That is the great task of sacred architecture. In this paper, the research will be carried out by a comparative analysis of materialization of central theological concepts of the great religions of Hinduism, Buddhism, Judaism, Islam, and Christianity into architecture. 


\section{Comparative analysis of world major religious architectures}

\subsection{Hinduism}

Eastern religions as Hinduism and Buddhism share the common theological concept of reincarnation and the transmigration of souls that pass through the infinite cycles of birth and rebirth. Similarly, they offer answers to how the soul can be relieved of temporal existence. Hinduism relies on the belief in the multitude of Gods that permeate everything created, so Hinduism is a pantheistic religion. There are three supreme Gods: Shiva, Vishnu and Brahma. Shiva is a God of procreative energy, as well as destroyer. Vishnu is a creator that embodies goodness and mercy. Brahma is the supreme deity, the creator. The purpose of life is to humble oneselves before Gods because they can help the faithful to free themselves from the cycles of birth and rebirth and to release the soul (atman) whose purpose is to unite with Brahma. The Hindu temple has the role of mediator between Gods and believers. The faithful worship the pantheon of gods identified with the natural elements. In the early days of religion Gods lived in the mountains caves. They permeate nature. Therefore, the architecture of Hindu temples refers to the first places that Gods inhabited. In Hindu architecture, we can find the formal expression of the vertical mound (mountain) arising over the lightless sanctuary garbhagriha (cave) containing the sacred image as a symbol of the presence of God. The water as a symbol of purity and fertility played important role. The temples were often built on the banks of rivers, coasts, seashores. The sites where the temple was built were the Sites of convergence between two or more rivers. The temples are usually aligned on the cardinal directions. In that way, they are harmonized with Earth's position in Cosmos. The entrance to the temple is often situated on the east side. The reincarnation and samsara find their expressions in the geometry of mandala-based Hindu temples. Circumambulation realized in space expresses the reality of samsara as well as repetitive appearing of figural motifs on Hindu temples that express the reality of reincarnation. (Michell, 1999; Moffett, Fazio, 2004). During the history, Hinduistic shrines shared the same principles of architecture: the construction of the temple near the river, verticality over the lightless sanctuary, Mandala based plans, the alignment of the temple with cardinal directions, entrance on the east, repetitive architectural and sculptural elements. In contemporary Hinduism there is the continuum of the effort to maintain the main principles of architecture giving the architecture its mystagogic role.

\subsection{Buddhism}

The religion has been founded by Siddhartha Gautama (Buddha). Buddhism rests on the knowledge that the true path to salvation lies in the middle way between self indulgence and self-mortification. These truths, in conjunction with eight fold ways (right view, resolve, speech, conduct, livelihood, effort, recollection, and meditation) formed the basis for achieving nirvana or liberation from the eternal cycles of birth and rebirth. Buddha had not prescribed any particular architectural form for shrines. Unlike Hinduism in which the temples inhabit the Gods, the early Buddhists shrines were stupas that were erected over the relics of Buddha. The stupas were constructions of the hemispherical form provenance from traditional chaityas. In that form, they incorporated the cosmological associations of a circle and world mountain and dome of vertical world axis. Under the patronage of Asoka (Indian emperor of the Maurya Dynasty, who ruled almost the entire Indian subcontinent from c. 268 to 232 BC) the form of Buddhists stupas has been established. The clear form of hemisphere creates a symbolic link to the cyclical nature of existence. The sacred site was separated from its surroundings by a verdica. The path for a circumambulation symbol of samsara was defined. On the top of stupa there were harmica, the square railing and a chatra, the sculpture symbolising bodhi tree under which Buddha had the enlightenment. Unlike Hindu architecture, the early Buddhist architecture was deprived of richness of sculptural elements. Its ascetic character was in accordance with its aspiration to achieve nirvana. In the later Buddhist temples, the statue of Buddha was introduced. It became a central place of worship. The ascetic architectural spaces of regular geometry (octagonal, circle) recall the eight fold method of self-mortification to achieve nirvana but they are not places of encountering the divinity (Le Huu Phuoc, 2010, Moffett, Fazio, 2004). Contemporary examples of Buddhist architecture express central theological concepts of Buddhism and preserve its initial principles such as pure geometric concept, minimalism of form, absence of abundance of sculptural narrative elements considering architecture as a religious symbol. 


\subsection{Judaism}

In contrast to Eastern religions, Judaism relies on the idea of a God endowed with absolute omnipotence and who has been revealed to a man by the prophets. The man communicates with God and only subdued to him he can achieve salvation in the afterlife. The history of Salvation is marked by the moments of revelation in which God reveals its nature to a man in a special way. He reveals his nature through Abraham who established the first relationship between the Jewish people and God, whereas Moses establishes a strong alliance (covenant) with God who communicates to him his law on Mount Sinai. Two tablets of the Ten Commandments became the motive of raising the first Jewish shrine in the desert - a sacred tent. In the tent all the elements of the Jewish sacred space were defined, and later they will be reenacted in the Temple in Jerusalem whose nucleus was the Holy of Holies, where the Ark of Covenant was situated containing tablets of Ten Commandments (the first temple was built c.1000 and destroyed 586 BCE; the second temple was build 516 BCE and destroyed $70 \mathrm{CE}$ ). After the devastation of the temples, the Jews remained without a temple. The synagogues became places for gathering Jewish communities to prayer. After the Temple was destroyed, the architecture of synagogue expand first in Europe and then globally. A synagogue always contains an ark, called aron ha-kodesh or hekhal, where the Torah scrolls are kept. It also contains bimah, the raised platform where the service is led and Torah read. Those are the two most important accents of synagogue architectural space. Synagogue plans were generally unrestricted. It is therefore that the architectural styles of synagogues vary a lot. Generally, synagogues were built in the prevailing architectural style of the time and place where they were erected and they were expressions of Jewish identity using specific Jewish symbols not as a substrate of structural architectural concepts because real mystagogic dimension of Jewish sacred building belongs only to long-since destroyed Temple in Jerusalem. (Krinsky, 1996.)

\subsection{Islam}

The basic concept of Islam is the existence of a God who is absolutely transcendent and revealed to a man by the Prophet Muhammad, who lived in Mecca periodically secluded in a mountain cave named Hira in order to spend nights in prayer. He reported being visited by angel Jibrill in the cave, and receiving his first revelation from God. The revelations were collected in a holy book - Qur'an which expressed in Arabic the message of Islam. Muslims have received the revelation from God, but God remained outside the world. Men cannot say anything about him except what has been revealed in the Qur'an. From the time of very first mosques like Great Mosque of Damascus until nowadays, despite different influences of other cultures, the idea of Islamic architecture was to establish a liturgical area, praying site with no consecrated elements of space, but all elements subordinated to the service of prayer. Several most important elements of place have been established at the very beginning of the history of mosques. It contained a court with ablution fountain, as well as the praying space including these elements: mihrab, a semicircular niche in the wall of a mosque that indicates the qibla and Minbar (is a pulpit for the prayer leader) (Hattstein, Delius, 2011). The crucial element of architecture of mosque is quibla direction toward Mecca where God revealed himself to Muhammad and where Ka'ba is settled, the liturgical centre of Muslim world. This is the direction that Muslims should face when praying. Despite the different types of space organization through history, the architecture of mosques bear witness to the Muslim's understanding of God. Muslim's God is not incarnate. He is a God who revealed himself to a man, but man cannot comprehend his essence. Human experience could be compared to looking to the light through a veil, never clear and absolute. The mosque architecture demonstrates this reality. The architecture of mosques took some elements of Christian and Jewish architecture to emphasize this reality like a dome representing the vertical orientation towards "heaven," toward the transcendental reality. The sense of rhythm and spirit of geometry which we regularly find in mosques's architecture are gleams of the perfect nature of God, so arabesques are the most common decoration speaking of this reality. Carefully shaped light in mosques's architecture is the most loquacious element of architecture that speaks about the nature of God (Burckhardt, 2009). The hereliving life is merely scratched by the shroud through which we can never see absolutely transcendent, but we can scent it as a flashing light which penetrates the Islamic mosque. The treatment of walls, facades and different surfaces of mosques in their different colors and pattern's tend to be experienced as immaterial or as an expression of the Divine Unity underlying the inexhaustible variety of the world. The aniconic reality of Islam architecture witnesses the same principle. God has remained outside the world and cannot be said in the figurative forms of here-living life. 
Preserving the functional organization of the praying hall mostly interpreted as one space whose accents are mihrab and minbar, historical and contemporary examples of Islamic architecture maintaining the important symbols of mosque architecture: use of geometrical elements, treatment of walls that permit the light to enter in a specific way, the treatment of facades in different colors and patterns etc. Thus symbols prevailing in the architecture reveal the nature of Islam's God.

\subsection{Christianity}

Christianity is a religion derived from Judaism. It inherits the same monotheistic concept of God as absolute transcendent reality. However, the Christian understanding of God adds to the Judaic concept the dimension of the concept of incarnated God, of God who embodied himself in the person of Jesus Christ. The life of Jesus became the bridge that connects reality with eternity. Christ showed the way by which man can partake in the life of God. The Mystery of the Trinity of God: Father, Son and Holy Spirit is the base of Christianity. Christianity is the religion of life oriented toward the transcendental reality in which its ultimate meaning is situated. That is why Christianity successfully "inhabits" the typology of the Roman basilica, whose longitudinal form assumes the theme of orientation towards the eschatological goal. Longitudinal form became the basic architectural typology that dominates the history of Christian architecture. The most important Christian symbol - Latin cross - was incorporated in that form and dominated in Christian sacred architecture plans during history. Sometimes, it assumed the form of Greek cross depending of the emphasis in theological thought (Krautheimer, 1984.) The crucial accent in the Christian sacred space was held by the altar. During whole Christian history, it was the symbol of the touch of heaven and earth, the symbol of Jesus's sacrifice and the memory of the Last Supper renewed within every Eucharist. The position of altar varied according to the emphasis in liturgy but it always remained the central architectural theme mostly accentuated with dome as a symbol of openness to transcendental reality. Other liturgical elements like ambo, tabernacle, baptistery etc. were always subordinated to the importance of altar in space, but they retained their place and their symbolic meaning in the spatial hierarchy in harmony with modifications in liturgy. The important differences between Christian sacred architecture from the past and the sacred architecture of 20th and the present century is the idea of inner sense of sacred building. In the different ways, with different architectural styles of architecture of the past testifies to the effort of constructing buildings giving them the mystagogic role and expressing core theological conxepts of Christianity. The plan was considered as a symbol, and the disposition of liturgical elements had their symbolic meaning. The harmony, proportion, order were considered the ways of participating in the beauty as an inherent characteristic of Christian God himself. The architecture itself was the privileged path of participation in the mystery of sacred experience. In the 20th century, we testify to a change in paradigms. The challenge of big transformations of society, of transformation of architectural concepts affected also the Christian sacred architecture. The beginning of the 20th century was the time when crisis in liturgy directed the path of finding the authenticity in sacred architecture in liturgy considering liturgy as a mere function of sacred architecture. This idea was in the accordance with the modernistic ideas of architectural theory like "form follows function." That approach leads to considering sacred buildings as a functional accommodation of community, reducing liturgy only to function, depriving both the liturgy and architecture of its symbolic and mystagogic character. In that way, it is obvious that the impoverishment of the sacramental reality of the Christian faith has occurred. (Benedetti,1995; Valenziano, 2005) The other way the problem of sacred architecture is currently manifest is the aesthetic criteria. The pervasive conceptualist trends in the artistic world deprived of ontological meaning influenced also sacred architecture. Art is mostly understood or as a creation of objects of pleasure, of mere beauty, aesthetic apeal or as an object with concept itentionally shifted from expected reality with shock as mere goal, rather than transfering some inner meaning. Consenquently, art losts its ontological value, its value of a symbol and its mystagogic character in the case of Christianity (Sokol Gojnik, 2017) The Second Vatican Council abolished the canon in sacred architecture. It opened the space of research of authenticity of material traces of the faith, so the experiments conducted in the past century have their value. But, the mere functional or aesthetic approach is not enough to envelop the phenomenon of Christian sacrum. All elements of sacred space play important role in the experience of faith and so does architectural space. The symbols that permeate reality allow the life of Christian faith. They are "channels" that empowers pre-taste of eternity and they are recognisable in sculpture, paintings, music, liturgy, and architecture. So, did contemporaneity in 
its experimental approach find the way to express symbols? Do architectural forms derive from their theological symbolic sense? Do contemporary churches possess the mystagogic character to open the path towards experienceing the faith?

\section{Conclusion}

Comparative analyses of architectural expressions of five world most important religions show that each religion in the different way attempted to materialise their theological essence through architecture considering architecture an important element of immersing into mystery of faith. In the majority of examples of contemporary Christian sacred architectural projects, however, the design starting point is eather functional organisation of space or aesthetic appeal while the symbolic layer of space itself is left to iconography - painting or sculptural interventions. Space itself is considered to be successful if it is functionally correct and meets the contemporary and trendy aesthetic criteria. It has been observed that during the past, space itself and its iconographic layer were interwined and both carriers of symbolic meaning providing architecture with its mystagogic value. In contemporaneity, the paradigms like „less is more“ or „form follows function“ lead into noose that only functionalistic-aestetic approach is the basic criteria. So, the space itself did not always succeed in finding the way of assuming the role of intermediator of symbols inherent to Christianity and mediator of central theological concepts of Christianity. This insight is partly understandable in the context of tumultuous changes that occurred in the West in the 20th and the present century. The domination of individualism, anthropocentrism, and subjectivism in the context of changes in liturgy obscured the centuries-old way of comprehending of the task of sacred architecture as mediator between here living and transcendental reality. In the case of sacred architecture forms itself are not for their own sake but for the sake of theological meaning.

\section{References}

Benedetti, S. (1995). Architettura sacra oggi. Rome: Itaca.

Burckhardt, T. (2009). Art of Islam; language and meaning. World of Islam Festival Publishing Co. Ltd.

Guardini, R. (1998). The spirit of liturgy. New York: The Crossroad Publishing Company.

Hani, J. (1996). Il simbolismo del tempio cristiano. Rome: Edizioni Arkeios.

Hattstein, M., \& Delius, P. (2011). Islam art and architecture. Potsdam: H. F. Ullmann Publishing Gmbh.

Krautheimer, R. (1984). Early Christian and Byzantine Architecture. The Yale University Press.

Krinsky, C. H. (1996). Synagogues of Europe: Architecture, History, Meaning. New York: Dover Publications.

Le Huu Phuoc. (2010). Buddhist Architecture. Grafikol.

Michell, G. (1999). The Hindu Temple: An Introduction to Its Meaning and Forms. Chicago: University of Chicago Press.

Moffett, M., \& Fazio, M. (2004). A World History of Architecture. London: Laurence King Pub.

Sokol Gojnik, Z. (2017). Sakralna arhitektura Zagreba u 20. Stoljeću. Katoličke liturgijske građevine. Zagreb: UPI 2 M Books.

Šaško, I. (2005). Liturgijski simbolički govor. Per signa sensibilia. Zagreb: Glas Koncila.

Valenziano, C. (2005). Architetti di chiese. Bologna: Edizioni Dehoniane Bologna. 